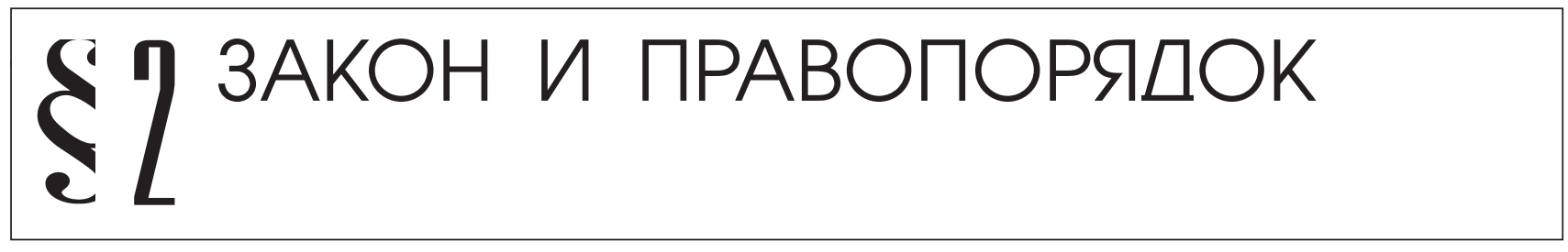

Кабанов П.А.

\title{
АНТИКОРРУПЦИОННАЯ ПРОПАГАНДА КАК ИНСТРУМЕНТ ПРОТИВОДЕЙСТВИЯ КОРРУПЦИИ В РЕСПУБЛИКЕ ТАТАРСТАН: ВОПРОСЫ ПОВЫШЕНИЯ КАЧЕСТВА ПРАВОВОГО РЕГУЛИРОВАНИЯ
}

\begin{abstract}
Аннотация: В работе впервые в российской юридчческой науке рассматриваются вопросы повышения качества правового регулирования на региональном уровне одного из наиболее действенных инструментов современной региональной государственной политики противодействия коррупции - антикоррупиионной пропаганды. Автором дается критическая оиенка состояния правового регулирования антикоррупиионной пропаганды в одном из субъектов Российской Федерации - Республике Татарстан, вскрываются причины низкого качества правового регулирования (недооценка органами государственной власти этого инструмента антикоррупционной политики и избирательное исполнение рекомендаций по его подготовке) и предлагаются основные меры по его совершенствованию. В числе основных направлений совершенствования правового регулирования института антикоррупционной пропаганды автор предлагает: а) пересмотреть содержание правовой дефиниции «антикоррупиионная пропаганда», закрепленной в региональном антикоррупционном законодательстве; б) создать межведомственную рабочую группу по разработке нормативного правового акта по организации и осуществлении антикоррупиионной пропаганды на региональном уровне, разработать, обсудить $и$ принять этот комплексный кодифицированный акт.
\end{abstract}

Review: The article for the first time in the Russian legal science includes analysis of the issues of quality improvement of legal regulation of anti-corruption propaganda at the regional level, this type of propaganda being one of the most efficient instruments of the modern Russian regional state anti-corruption policy. The author provides critical evaluation of the current situation in legal regulation of anti-corruption propaganda in one of the constituent subjects of the Russian Federation - the Republic of Tatarstan. He shows the reasons for the low quality of legal regulation (underestimation of this instrument of anti-corruption policy by the stat government body, selective implementation of recommendations on its development) and makes propositions for the improvement of the situation. Among the key directions for the improvement of legal regulation of anti-corruption propaganda the author offers the following: a) to review the legal definition of the "anticorruption propaganda"; b) to form an inter-departmental working group in order to draft a normative legal act on organization and implementation of anti-corruption propaganda at the regional level, to draft, discuss and adopt this complex codified act.

Ключевые слова: коррупџия, противодействие коррупции, антикоррупционная пропаганда, антикоррупиионная политика, антикоррупционное воспитание, антикоррупиионная агитация, антикоррупционное информирование, антикоррупционное мировоззрение, антикоррупционное просвещение, Республика Татарстан

Keywords: corruption, fighting corruption, anti-corruption propaganda, anti-corruption policy, anticorruption education, anti-corruption agitation, anti-corruption information, anti-corruption worldview, anti-corruption awareness, the Republic of Tatarstan. 
B опросы совершенствования механизмов и инструментов системы противодействия коррупции в современном российском обществе на протяжении длительного периода находятся в центре внимания научного сообщества и представителей органов государственной власти. Им посвящено значительное количество научных, учебных, методических и публицистических работ различного объема и качества. Однако до настоящего времени не опубликовано ни одного крупного исследования, посвященного вопросам эффективности такого инструмента противодействия коррупции как антикоррупционная пропаганда, хотя и не закрепленного в федеральном антикоррупционном законодательстве, но получившее широкое распространение в регионах. В распоряжении современных исследователей имеются лишь две научные публикации в федеральных научных изданиях авторитетного российского криминолога профессора Г.Н. Горшенкова. ${ }^{1}$ В связи с этим становится очевидным, что исследование этого вопроса необходимо начинать именно с анализа и оценки регионального опыта использования этого инструмента антикоррупционной политики. Тем более, что о важности его правового регулирования в Республике Татарстан говорится отечественными специалистами.

Обращение региональных органов государственной власти к вопросам использования антикоррупционной пропаганды были обусловлены тем, что специалисты в области противодействия коррупции обращали внимание на то, что результативность антикоррупционной деятельности возможна лишь при формировании антикоррупционного сознания ${ }^{23}$ и антикоррупционного мировоззрения в обществе с использованием СМИ. ${ }^{4}$

\footnotetext{
${ }^{1}$ Горшенков Г.Н. Антикоррупционная пропаганда как инструмент противодействия коррупции: понятие и сущностное содержание // Следователь. - 2010. - №10. - С.32-38; Его же. Антикоррупционная пропаганда: понятие и содержание // Актуальные проблемы экономики и права. - 2010. - №4 (16). - С.39-46.

2 Агеев В.Н. Правовые средства противодействия коррупции в Республике Татарстан // NB: Административное право и практика администрирования. - 2013. - №1. - С.146- 169.

3 Лопатин В.Н. О системном подходе к антикоррупционной политике // Государство и право. - 2001. - №7. - С.27.

${ }^{4}$ Резолюция Круглого стола по теме «Социальная ответственность бизнеса и перспектива реформирования административной системы в свете антикоррупционной политики» // Социальная ответственность бизнеса и перспектива реформирования административной системы в свете антикоррупционной политики в Республике Татарстан (материалы круглого стола 7 апреля 2004 года) / под ред. д-ра эконом. наук Р.Ф. Муратова. - Казань, 2004. - С.8-9.
}

Разработчики системы региональных антикоррупционных мер понимали, что формирование этих антикоррупционных ценностей не возможно без использования системы информационного воздействия на общество. Именно этот инструмент целенаправленного системного воздействия на сознание населения они назвали антикоррупционной пропагандой, включающим в себя такие направления как антикоррупционное воспитание, антикоррупционное просвещение и антикоррупционное информирование. Официальное использование антикоррупционной пропаганды как одного из инструментов противодействия коррупции было закреплено в 2005 году в Стратегии антикоррупционной политики Республики Татарстан, ${ }^{5}$ содержание и механизмы использования которой в этом документе не раскрывалось. Поэтому Кабинетом Министров Республики Татарстан было дано поручение Агентству Республики Татарстан по массовой коммуникации «Татмедиа», в срок до 1 октября 2005 года, разработать мероприятия по антикоррупционной пропаганде в Республике Татарстан. Подготовленные региональным агентством по массовым коммуникациям мероприятия по антикоррупционной пропаганде в последующем были включены самостоятельным разделом в Республиканскую программу по реализации Стратегии антикоррупционной политики Республики Татарстан на 20062008 годы, получившим одноименное наименование - «Антикоррупционная пропаганда». ${ }^{7}$ В последующих программных республиканских нормативных правовых актах по вопросам противодействия кор-

\footnotetext{
${ }^{5}$ О Стратегии антикоррупционной политики Республики Татарстан: Указ Президента Республики Татарстан от 8 апреля 2005 года №УП-127 // Ведомости Государственного Совета Татарстана. - 2005. - №4 (Ч.ІІ). - Ст.460.

${ }^{6}$ О мерах реализации Стратегии антикоррупционной политики Республики Татарстан: Постановление Кабинета Министров Республики Татарстан от 12 августа 2005 года №400 // Сборник постановлений и распоряжений Кабинета Министров Республики Татарстан и нормативных актов органов исполнительной власти. - 2005. - №31-32. - Ст.0750.

${ }^{7}$ Об утверждении Республиканской программы по реализации Стратегии антикоррупционной политики Республики Татарстан на 2006-2008 годы: Постановление Кабинета Министров Республики Татарстан от 16 октября 2006 года №516 // Сборник постановлений и распоряжений Кабинета Министров Республики Татарстан и нормативных актов республиканских органов исполнительной власти. - 2006. - №40. - Ст.1047.
} 


\section{Право и политика 9 (165) • 2013}

рупции этот инструмент постоянно сохранялся, ${ }^{8}$ сохраняется он и в действующей республиканской антикоррупционной программе. ${ }^{9}$

Под воздействием региональных нормативных правовых актов использование термина «антикоррупционная пропаганда» перешло на муниципальный уровень. Так, в Программе антикоррупционной политики в Верхнеуслонском районе Республики Татарстан было указано, что одним из важнейших направлений антикоррупционной политики должно быть изменение общественного сознания под влиянием антикоррупционной пропаганды. Здесь же было предложено использование основного направления антикоррупционной пропаганды - антикоррупционное просвещение. ${ }^{10}$ Аналогичные положения были внесены антикоррупционные программы и других муниципальных образований Республики Татарстан. ${ }^{11}$

Важнейшим этапом в формировании антикоррупционной пропаганды как регионального инструмента противодействия коррупции стало принятие Закона Республики Татарстан «О противодействии коррупции в Республике Татарстан», поскольку в части 3 статьи 12 этого закона впервые в России давалось правовое определение антикоррупционной пропаганды. Это определение в последующем «переместилось» в качестве правовой дефиниции в большинство региональных анти-

${ }^{8}$ Об утверждении республиканской программы по реализации Стратегии антикоррупционной политики Республики Татарстан на 2009-2011 годы: Постановление Кабинета Министров Республики Татарстан от 22 сентября 2008 года №693 (в ред. от 18.08.2010 №666) // Сборник постановлений и распоряжений Кабинета Министров Республики Татарстан и нормативных актов республиканских органов исполнительной власти. - 2008. - №37. - Ст.1548.

${ }_{9}^{9}$ Об утверждении Комплексной республиканской антикоррупционной программы на 2012-2014 годы: Постановление Кабинета Министров Республики Татарстан от 18 августа 2011 года №687 // Сборник постановлений и распоряжений Кабинета Министров Республики Татарстан и нормативных актов республиканских органов исполнительной власти. - 2011. - №33. - Ст.1612.

${ }^{10}$ Об утверждении Программы антикоррупционной политики в Верхнеуслонском районе Республики Татарстан: Постановление Главы Администрации Верхнеуслонского района от 23 сентября 2005 г. N 447 // Документ официально опубликован не был и находится в личном архиве автора.

${ }^{11}$ Об антикоррупционных мерах в Камско-Устьинском районе: Постановление Главы Администрации Камско-Устьинского района от 19 сентября 2005 года № 292; О создании постоянной рабочей группы по вопросам реализации антикоррупционной политики в Буинском районе и г. Буинске: Постановление Главы Администрации Буинского района и г. Буинск от 20 сентября 2005 г. N 619 // Документы официально опубликованы не были и находятся в личном архиве автора. коррупционных законов. Частью 4, этой же статьи, обязанности по организации антикоррупционной пропаганды были возложены на специальный уполномоченный орган Республики Татарстан в сфере массовой коммуникации, а осуществление антикоррупционной пропаганды стало одной из функций уполномоченного органа во взаимодействии с другими субъектами антикоррупционной политики. ${ }^{12}$ В числе таких субъектов, оказывающих содействие уполномоченному органу в реализации антикоррупционной пропаганды в форме подготовки предложений о формировании государственного заказа и грантов для координации и стимулирования антикоррупционной пропаганды, оказался и созданный отдел по реализации антикоррупционной политики Республики Татарстан. ${ }^{13}$ Ранее на этот орган возлагалась лишь функция по выпуску информационно-просветительских материалов по вопросам антикоррупционной деятельности и задачи по антикоррупционному просвещению и формированию антикоррупционного мировоззрения. ${ }^{14}$ В последующем, в процессе реформирования института специального уполномоченного государственного органа по противодействию коррупции Республики Татарстан, эта функция была сведена лишь к взаимодействию с уполномоченным органом Республики Татарстан в сфере массовых коммуникаций по вопросам организации антикоррупционной пропаганды. ${ }^{15}$

Для повышения качества противодействия коррупции Президент Республики Татарстан возложил задачу по содействию формирования системы антикоррупционной пропаганды на созданный им

\footnotetext{
${ }^{12}$ О противодействии коррупции в Республике Татарстан: Закон Республики Татарстан от 4 мая 2006 года №34-3РТ // Ведомости Государственного Совета Татарстана. - 2006. - №5. - Ст.1464.

${ }^{13}$ Об утверждении Положения об отделе по реализации антикоррупционной политики Республики Татарстан: Указ Президента Республики Татарстан от 7 августа 2006 года №УП-284 // Ведомости Государственного Совета Татарстана. - 2006. - №7-8 (Часть II). - Ст.1757.

${ }^{14} \mathrm{O}$ создании постоянно действующего органа по реализации антикоррупционной политики Республики Татарстан: Указ Президента Республики Татарстан от 1 июня 2005 года №УП-220 // Ведомости Государственного Совета Татарстана. - 2005. - 6 (II часть). - Ст.705.

${ }^{15}$ Об Утверждении Положения об Управлении Президента Республики Татарстан по вопросам антикоррупционной политики: Указ Президента Республики Татарстан от 31 января 2011 года N УП-37 // Сборник постановлений и распоряжений Кабинета Министров Республики Татарстан и нормативных актов республиканских органов исполнительной власти. - 2011. - №12. - Ст. 0372.
} 
Республиканский совет по реализации антикоррупционной политики, ${ }^{16}$ в составе которого была образована Комиссия по антикоррупционному образованию и антикоррупционной пропаганде. В связи с изменением функций, состава и наименования этого совещательного регионального антикоррупционного органа была изменена редакция задачи. Сейчас эта задача Совета при Президенте Республики Татарстан по противодействию коррупции сформулирована следующим образом: «подготовка предложений по формированию системы антикоррупционной пропаганды». ${ }^{17}$

С учетом важности антикоррупционной пропаганды как инструмента противодействия коррупции в регионе о её состоянии и эффективности использования было 18 сентября 2007 года проведено заседание Республиканского совета по реализации антикоррупционной политики, где были предложены меры по её эффективности. Наиболее важными из предложенных мер были признаны: а) разработка концепции антикоррупционной пропаганды в Республике Татарстан; б) проведение специальных обучающих семинаров для журналистов, освещающих антикоррупционную тематику; в) подведение специального журналистского конкурса «СМИ против коррупции»; г) принять меры по созданию социальной рекламы антикоррупционной направленности. ${ }^{18}$ Из предложенных направлений совершенствования антикоррупционной пропаганды в полном объеме было исполнено только проведение журналистского конкурса и созданы объекты социальной рекламы. Однако наиболее важные организационно-правовые меры по созданию системы антикоррупционной пропаганды не были выполнены. До настоящего времени не разработана Концепция анти-

\footnotetext{
${ }^{16}$ О Республиканском совете по реализации антикоррупционной политики: Указ Президента Республики Татарстан от 18 августа 2006 года №УП-313 // Сборник постановлений и распоряжений Кабинета Министров Республики Татарстан и нормативных актов республиканских органов исполнительной власти. - 2006. - №32. - Ст.0870.

17 О Совете при Президенте Республики Татарстан по противодействию коррупции: Указ Президента Республики Татарстан от 21 февраля 2011 года №УП-71 // Сборник постановлений и распоряжений Кабинета Министров Республики Татарстан и нормативных актов республиканских органов исполнительной власти. - 2011. - №13. - Ст.0420.

18 О состоянии антикоррупционной пропаганды в Республике Татарстан: Решение Республиканского совета по реализации антикоррупционной политики от 18 сентября 2007 года // Документ официально не опубликован и находится в личном архиве автора.
}

коррупционной пропаганды в Республике Татарстан либо иной организационно-правовой нормативный правовой акт по вопросам организации и проведения антикоррупционной пропаганды. Не проведено и обучение журналистов освещающих, антикоррупционную проблематику, хотя образовательная программа повышения квалификации для этой категории лиц в республике уже разработана и опубликована. ${ }^{19}$ Более того, не могут не настораживать, результаты социологических опросов по вопросам эффективности антикоррупционной пропаганды, проведенных в республике в 2009-2010 годах. Согласно, полученным данным $32 \%$ респондентов выразили неудовлетворенность информационным обеспечением борьбы с коррупцией в республике, а $15,6 \%$ не удовлетворена вкладом средств массовой информации в антикоррупционную пропаганду. ${ }^{20} \mathrm{~B}$ последующих республиканских сводных отчетах (за 201121 и $2012^{22}$ годы) и других информационных материалах, ${ }^{23}$ невзирая на важность этого вопроса и наличия результатов социологических опросов этот показатель не был приведен. В числе основных причин отсутствия комплексного документа регулирующего вопросы организации и осуществления антикоррупционной пропаганды в Татарстане следует признать недооценку этого инструмента антикоррупционной политики и даже пренебрежительное отношение к нему со стороны органов публичной власти, а так же избирательное исполнение рекомендаций по его подготовке.

В начале 2013 года для повышения информированности населения по вопросам противодействия коррупции Кабинетом Министров Республики Татарстан был принят нормативный правовой акт, утвердивший Единые требования к размещению и наполнению разделов официальных сайтов ис-

\footnotetext{
${ }^{19}$ Бикеев И.И., Горшенков Г.Н., Кабанов П.А., Рахимов С.Ф. Антикоррупционная пропаганда: вопросы организации и осуществления (учебная программа курса) // Следователь. - 2012. - №10. - C.23-26.

${ }^{20}$ Сводный отчет о состоянии коррупции и реализации мер антикоррупционной политики в Республике Татарстан в 2010 году. - Казань, 2011. - С.23.

${ }^{21}$ Сводный отчет о состоянии коррупции и реализации мер антикоррупционной политики в Республике Татарстан в 2011 году. - Казань, 2012.

${ }^{22}$ Сводный отчет о состоянии коррупции и реализации мер антикоррупционной политики в Республике Татарстан в 2012 году. - Казань, 2013.

${ }^{23}$ Антикоррупционный мониторинг (2012год). - Казань, 2013.
} 
DOI: 10.7256/1811-9018.2013.9.9466

При цитировании этой статьи сноска на dоі обязательна

\section{Право и политика 9 (165) • 2013}

полнительных органов государственной власти Республики Татарстан в информационно-телекоммуникационной сети «Интернет» по вопросам противодействия коррупции. ${ }^{24}$

Изложенное выше свидетельствует о том, что в Республике Татарстан методом проб и ошибок последовательно происходит формирование системы антикоррупционной пропаганды как одного из инструментов региональной антикоррупционной политики. Однако такое изменение не носит системного и управляемого характера. На наш взгляд, в числе многих факторов объективного и субъективного характера этому способствует противоречивость и неполнота правового регулирования данного направления антикоррупционной деятельности, в том числе и отсутствие комплексного нормативного правового акта, регулирующего вопросы организации и проведения антикоррупционной пропаганды.

Как нам представляется, даже действующее региональное антикоррупционное законодательство в значительной мере не способствует качественному изменению положению дел в области организации и осуществления антикоррупционной пропаганды. В частности, правовая дефиниция «антикоррупционная пропаганда» не соответствует содержанию этого вида профессиональной деятельности, которая сформулирована в законе как целенаправленная деятельность средств массовой информации, координируемая и стимулируемая системой государственных заказов и грантов, содержанием которой является просветительская работа в обществе по вопросам противостояния коррупции в любых ее проявлениях, воспитание в населении чувства гражданской ответственности за судьбу реализуемых антикоррупционных программ, укрепление доверия к власти. ${ }^{25}$

Судя по тексту республиканского закона о противодействии коррупции, основными содержательными

\footnotetext{
${ }^{24}$ Об утверждении Единых требований к размещению и наполнению разделов официальных сайтов исполнительных органов государственной власти Республики Татарстан в информационно-телекоммуникационной сети «Интернет» по вопросам противодействия коррупции: Постановление Кабинета Министров Республики Татарстан от 4 апреля 2013 г. №225 // Сборник постановлений и распоряжений Кабинета Министров Республики Татарстан и нормативных актов республиканских органов исполнительной власти. - 2013. - №29. - Ст. 0919.

${ }^{25}$ О противодействии коррупции в Республике Татарстан: Закон Республики Татарстан от 4 мая 2006 года №34-3РТ // Ведомости Государственного Совета Татарстана. - 2006. - №5. - Ст. 1464.
}

признаками этого определения антикоррупционной пропаганды являются:

1) определение субъектов этого вида деятельности - уполномоченный орган в сфере массовой коммуникации, средства массовой информации и другие субъекты антикоррупционной политики;

2) указание на объект пропагандистского воздействия - общество;

3) постановка основных целей стоящих перед антикоррупционной пропагандой.

По мнению регионального законодателя, в качестве основных целей региональной антикоррупционной пропаганды выступают: а) просветительская работа в обществе по вопросам противостояния коррупции в любых ее проявлениях (антикоррупционное просвещение); б) воспитание в населении чувства гражданской ответственности за судьбу реализуемых антикоррупционных программ (антикоррупционное воспитание); в) укрепление доверия к власти. Очевидно, что первые две цели, заложенные в определении, могут достигаться с помощью антикоррупционной пропаганды, однако, только с помощью этого антикоррупционного инструмента не возможно достичь третьей цели - укрепить доверие к органам государственной власти. Поскольку авторитет органов публичной власти у населения зависит не столько от качества и объема антикоррупционной пропаганды (пиара), сколько от реальных дел, направленных на повышение уровня его жизни, а поэтому данная цель является факультативной (дополнительной) при осуществлении антикоррупционной пропаганды иногда она просто не достижима. Например, этой цели невозможно достичь при описании или изобличении злоупотреблений должностных лиц в определенной сфере социального управления при проведении журналистского расследования. В таких случаях, журналисты чаще добиваются противоположной цели - порождают недоверие к органам публичной власти и их должностным лицам и/или дискредитируют их. Вызывает настороженность и утверждение разработчиков закона о том, что антикоррупционная пропаганда - это деятельность средств массовой информации. Ведь средства массовой информации, в соответствии с положениями статьи 2 Закона «О средствах массовой информации» ${ }^{26}$ - это лишь инструментарий, с помо-

\footnotetext{
${ }^{26} \mathrm{O}$ средствах массовой информации: Закон РФ от 27 декабря 1991 года №2124-1 (в ред. от 2 июля 2013 года №185-Ф3) // Российская газета. - 1992. -8 февр.
} 
щью которого информация доходит до потребителя. Здесь предпочтительнее выглядит положение о том, что субъектами организации и осуществления антикоррупционной пропаганды, наравне с другими, могут выступать учреждения массовой коммуникации (редакции, информационные агентства, компании, бюро и т.д.) или их представители - журналисты.

Разумеется, что определение «антикоррупционной пропаганды» было предложено впервые, когда не было еще серьезных научных разработок раскрывающих его сущность и механизмы реализации. Однако время идет вперед, а вслед за ним меняются представления о содержании этого антикоррупционного инструмента. В представлении современных специалистов в сфере противодействия коррупции антикоррупционная пропаганда является универсальным инструментальным информационного (идеологического, социально-психологического) воздействия на общество и основными его целями являются - формирование антикоррупционного мировоззрения, а через него и антикоррупционного поведения. При этом антикоррупционная пропаганда может выступать как средством антикоррупционного просвещения - распространение достоверных знаний о коррупции и противодействии коррупции, так и средством антикоррупционного воспитания формирования антикоррупционного правосознания личности, подготовки её к общественно полезному антикоррупционному поведению, то есть такому поведению, которое приобретает (рекрутирует) сторонников идеи противостояния коррупции. Таким образом, в определении антикоррупционной пропаганды неверно сформулированы как её основные цели, так и указаны субъекты по использованию этого инструмента антикоррупционной политики.

Следовательно, предложенная региональными законодателями правовая дефиниция «антикоррупционной пропаганды» сформулирована с существенными недостатками технико-правового характера и нуждается в изменении.

Однако эффективность антикоррупционной пропаганды зависит не столько от её правового определения, сколько от содержания, которое отражается в нормативных правовых актах. Содержание и механизмы антикоррупционной пропаганды как профессиональной деятельности заложены в республиканских программах по противодействию коррупции. В соответствии с ними в качестве основных форм осуществления антикоррупционной пропаганды выступают разрозненные не объединенные одной целью и сопутствующей ей задачами:

а) публикация статей и репортажей по вопросам противодействия коррупции;

б) проведение журналистских конкурсов по освящению вопросов противодействия коррупции;

в) проведение конкурсов социальной рекламы противодействия коррупции;

г) изготовление и распространение печатной продукции антикоррупционной направленности (буклеты, календари, плакаты);

д) информирование населения через массово-коммуникативную сеть «Интернет» о мерах по противодействию коррупции. ${ }^{27}$

Вместе с тем нужно отметить, что вне рамок региональных антикоррупционных программ в Республике Татарстан получили развитие и осуществляются иные формы антикоррупционной пропаганды, направленные на формирование антикоррупционного мировоззрения определенных категорий населения. Например, республиканский конкурс детских рисунков антикоррупционной направленности, проведенный Министерством образования и науки Республики Татарстан $^{28}$ классные часы, родительские собрания, диспуты, деловые игры, викторины, выставки книг, конкурсы плакатов, видеороликов и рефератов по во-

\footnotetext{
${ }^{27}$ Об утверждении Республиканской программы по реализации Стратегии антикоррупционной политики Республики Татарстан на 2006-2008 годы: Постановление Кабинета Министров Республики Татарстан от 16 октября 2006 года №516 // Сборник постановлений и распоряжений Кабинета Министров Республики Татарстан и нормативных актов республиканских органов исполнительной власти. - 2006. - №40. - Ст.1047; Об утверждении республиканской программы по реализации Стратегии антикоррупционной политики Республики Татарстан на 2009-2011 годы: Постановление Кабинета Министров Республики Татарстан от 22 сентября 2008 года №693 (в ред. от 18.08.2010 №666) // Сборник постановлений и распоряжений Кабинета Министров Республики Татарстан и нормативных актов республиканских органов исполнительной власти. - 2008. - №37. - Ст.1548; Об утверждении Комплексной республиканской антикоррупционной программы на 2012-2014 годы: Постановление Кабинета Министров Республики Татарстан от 18 августа 2011 года №687 // Сборник постановлений и распоряжений Кабинета Министров Республики Татарстан и нормативных актов республиканских органов исполнительной власти. -2011. - №33. - Ст.1612.

${ }^{28}$ О проведении республиканского конкурса детских рисунков антикоррупционной направленности: Приказ Министерства образования и науки Республики Татарстан от 5 июля 2012 года №4112/12 // Документ официально опубликован не был и находится в личном архиве автора.
} 


\section{Право и политика 9 (165) • 2013}

просам антикоррупционной тематики. ${ }^{29}$ Более того, в других субъектах Российской Федерации на региональном и муниципальном уровнях используются и иные формы антикоррупционной пропаганды:

а) конкурсы по разработке социальной рекламы (Республика Ингушетия, Мурманская область);

б) конкурсы по разработке общественных механизмов и способов противодействия коррупции (Архангельская область);

в) конкурсы на лучшую исследовательскую работу по антикоррупционной тематике (Республика Чувашия, Ханты-Мансийский автономный округ Югра, Кировская область);

г) конкурсы стенных газет «Молодежь против коррупции» (Пензенская область). Перечислять дополнительные формы проведения антикоррупционной пропаганды можно и дальше, но и приведенного достаточно, чтобы сделать вывод о том, что правовое регулирование этого инструмента антикоррупционной политики требует совершенствования. Но каким образом? На этот вопрос можно получить ответ лишь обратившись к опыту других субъектов Российской Федерации, где вопросы правового регулирования антикоррупционной пропаганды находятся на более высоком уровне.

Наиболее важными для нас, как по объему информации, так и по качеству правового регулирования выступают нормативные правовые акты исполнительных органов власти Санкт-Петербурга. В них, помимо законодательного закрепления антикоррупционной пропаганды в качестве инструмента региональной антикоррупционной политики, имеются и специальные нормативные акты по её организации и проведению, регулирующие порядок и технологические особенности осуществления антикоррупционной пропаганды. ${ }^{30}$

\footnotetext{
${ }^{29}$ Сводный отчет о состоянии коррупции и реализации мер антикоррупционной политики в Республике Татарстан в 2012 году. - Казань, 2013. - С.45-56.

${ }^{30}$ Об утверждении Порядка организации антикоррупционной пропаганды в Санкт-Петербурге: Постановление Правительства Санкт-Петербурга от 24 марта 2010 г. N 307 // Вестник Администрации Санкт-Петербурга. - 2010. - №4; Административный регламент Комитета по вопросам законности, правопорядка и безопасности исполнения государственной функции по участию в проведении антикоррупционной пропаганды в порядке, установленном законодательством Санкт-Петербурга (в ред. от 17.11.2010 N 256-р, от 02.03.2011 N 56-p, от 14.02.2012 N 40-p, от 12.03.2012 N 71-p) См.:Об утверждении административных регламентов Комитета по вопросам законности, правопорядка и безопасности по исполнению государственных функций: Распоряжение Комитета
}

Помимо Санкт-Петербурга комплексный нормативный правовой акт по организации и проведения антикоррупционной пропаганды в августе 2013 года принят правительством Республики Башкортостан, в котором определены понятие, цели и задачи антикоррупционной пропаганды, формы и субъекты её осуществления. ${ }^{31}$ Разумеется, что в ближайшее время аналогичный по содержанию кодифицированный нормативный правовой акт по организации и проведению антикоррупционной пропаганды органам государственной власти Республики Татарстан необходимо разработать, обсудить с заинтересованными лицами и принять. Как показывает опыт разработки нормативных правовых актов в сфере противодействия коррупции в республике, например, программных документов, для его разработки необходимо на основании решения Кабинета Министров Республики Татарстан создать межведомственную рабочую группу с привлечением представителей институтов гражданского общества.

Обращает на себя ещё одно обстоятельство, в большинстве субъектов Российской Федерации, где в нормативных правовых актах закрепляется организация и проведение антикоррупционной пропаганды за уполномоченным на то органом, автоматически через некоторое время в положение о нем вносят изменения, уточняющие его функции дополнением по организации и проведению антикоррупционной пропаганды. ${ }^{32}$ Однако, в нормативных правовых актах, регулирующих деятельность уполномоченного органа в сфере

по вопросам законности, правопорядка и безопасности Правительства Санкт-Петербурга от 22.06.2010 №138-р (ред. от 12.03.2012) // Информационный бюллетень Администрации Санкт-Петербурга. - 2010. - 19 июля. N 27; Об утверждении Методических рекомендаций по информированию населения Санкт-Петербурга о реализации антикоррупционной политики: Распоряжение Комитета по вопросам законности, правопорядка и безопасности Правительства Санкт-Петербурга от 10.02.2011 N 26-р // Документ официально опубликован не был и находится в личном архиве автора.

${ }^{31}$ Об утверждении Порядка организации антикоррупционной пропаганды государственными органами Республики Башкортостан: Постановление Правительства Республики Башкортостан от 5 августа 2013 г. №353 //(http://www.npa.bashkortostan.ru, 10.08.2013)

32 Об утверждении Положения об агентстве по делам печати и средствам массовой информации Архангельской области: Постановление Правительства Архангельской области от 18 февраля 2009 года №224-ПП // Волна. - 2009. - 31 декаб.; Об агентстве связи и массовых коммуникаций Астраханской области: Постановление Правительства Астраханской области от 29 мая 2009 г. №246-П (в ред. от 18.06.2013 №206-П) // Сборник законов и нормативных правовых актов Астраханской области. - 2009. 4 июня. - №24. 
массовой коммуникации Республике Татарстан, эта государственная антикоррупционная функция не указана лишь предусматриваются полномочия представление отчета о реализации мер антикоррупционной политики в специальный государственный орган по реализации антикоррупционной политики Республики Татарстан. ${ }^{33}$ Хотя как показывает опыт правового регулирования других инструментов противодействия коррупции в республике, например, антикоррупционного мониторинга, ${ }^{34}$ в основной нормативный правовой акт о деятельности уполномоченного органа вносились необходимые изменения. ${ }^{35}$

Изложенное нами выше позволяет сделать некоторые выводы о состоянии правового регулирования антикоррупционной пропаганды в Республике Татарстан. Во-первых, антикоррупционная пропаганда как инструмент противодействия коррупции активно используется в Республике Татарстан. Вопросы организации и

\footnotetext{
${ }^{33}$ Вопросы Республиканского агентства по печати и массовым коммуникациям «Татмедиа»: Постановление Кабинета Министров Республики Татарстан от 24.10.2012 №902 (ред. от 04.05.2013 №303) //Сборник постановлений и распоряжений Кабинета Министров Республики Татарстан и нормативных актов республиканских органов исполнительной власти. - 2012. - №83. - Ст. 2771.

$34 \mathrm{O}$ мерах по организации и проведению мониторинга эффективности деятельности органов исполнительной власти Республики Татарстан, территориальных органов федеральных органов исполнительной власти по Республике Татарстан, органов местного самоуправления муниципальных районов и городских округов Республики Татарстан по реализации: Указ Президента Республики Татарстан от 23 марта 2011 года №УП-148 // Сборник постановлений и распоряжений Кабинета Министров Республики Татарстан и нормативных актов республиканских органов исполнительной власти. - 2011. - №11. - №18. - Ст.0636; Об организации и проведении мониторинга эффективности деятельности органов исполнительной власти Республики Татарстан, территориальных органов федеральных органов исполнительной власти по Республике Татарстан, органов местного самоуправления муниципальных районов и городских округов Республики Татарстан по реализации антикоррупционных мер на территории Республики Татарстан: Постановление Кабинета Министров Республики Татарстан от 10 июня 2011 года №463 // Сборник постановлений и распоряжений Кабинета Министров Республики Татарстан и нормативных актов республиканских органов исполнительной власти. - 2011. - №25. - Ст. 1081.

${ }^{35} \mathrm{O}$ внесении изменений в Положение о Комитете Республики Татарстан по социально-экономическому мониторингу, утвержденное Постановлением Кабинета Республики Татарстан от 3 августа 2005 года №383 «Вопросы Комитета Республики Татарстан по социально-экономическому мониторингу»: Постановление Кабинета Министров Республики Татарстан от 10 июня 2011 года №470 // Собрание постановлений и распоряжений Кабинета Министров Республики Татарстан и нормативных актов республиканских органов исполнительной власти. - 2011. - №30. - Ст.1428.
}

проведения закреплены региональным антикоррупционным законодательством и рядом взаимосвязанных республиканских подзаконных нормативных правовых актов. Во-вторых, правовое регулирование антикоррупционной пропаганды как инструмента региональной антикоррупционной политики нуждается в существенном обновлении, начиная с правового определения её дефиниции, а также его систематизации и кодификации. В-третьих, органам государственной власти Республики Татарстан, в целях повышения качества правового регулирования антикоррупционной пропаганды, необходимо во взаимодействии с заинтересованными лицами начать разработку проектов нормативных правовых актов для комплексного решения вопросов организации и осуществления антикоррупционной пропаганды. Для достижения этой цели необходимо создание межведомственной рабочей группы с участием представителей институтов гражданского общества по разработке проектов этих документов.

Надеемся, что предложенные нами направления совершенствования правового регулирования антикоррупционной пропаганды в Республике Татарстан позволят упорядочить этот вид профессиональной деятельности и повлиять на повышение результативности этого инструмента республиканской антикоррупционной политики.

\section{Библиография:}

1. Бикеев И.И., Горшенков Г.Н., Кабанов П.А., Рахимов С.Ф. Антикоррупционная пропаганда: вопросы организации и осуществления (учебная программа курса) // Следователь. - 2012. - №10.

2. Горшенков Г.Н. Антикоррупционная пропаганда как инструмент противодействия коррупции: понятие и сущностное содержание // Следователь. -2010 . - №10.

3. Горшенков Г.Н. Антикоррупционная пропаганда: понятие и содержание // Актуальные проблемы экономики и права. - 2010. - №4 (16).

4. Лопатин В.Н. О системном подходе к антикоррупционной политике // Государство и право. - 2001. - №7.

5. Агеев В.Н. Правовые средства противодействия коррупции в Республике Татарстан // NB: Административное право и практика администрирования.-2013.-№1. 
DOI: 10.7256/1811-9018.2013.9.9466

При цитировании этой статьи сноска на dоі обязательна

\section{Право и политика $9(165) \cdot 2013$}

References (transliteration):

1. Bikeev I.I., Gorshenkov G.N., Kabanov P.A., Rahimov S.F. Antikorrupcionnaya propaganda: voprosy organizacii i osuschestvleniya (uchebnaya programma kursa) // Sledovatel'. - 2012. - №10.

2. Gorshenkov G.N. Antikorrupcionnaya propaganda kak instrument protivodeystviya korrupcii: ponyatie $\mathrm{i}$ suschnostnoe soderzhanie // Sledovatel'. - 2010. - №10.
3. Gorshenkov G.N. Antikorrupcionnaya propaganda: ponyatie i soderzhanie // Aktual'nye problemy ekonomiki i prava. - 2010. - №4 (16).

4. Lopatin V.N. O sistemnom podhode k antikorrupcionnoy politike // Gosudarstvo i pravo. - 2001. - №7.

5. Ageev V.N. Pravovye sredstva protivodeystviya korrupcii v Respublike Tatarstan// NB: Administrativnoe pravo i praktika administrirovaniya. - 2013. - №1. 